\title{
Uji Unjuk Kerja dan Durability 5000 Km Mobil Bensin 1497 Cc Berbahan Bakar Campuran Bensin-Bioetanol
}

\author{
Pasca Hariyadi Winanda \& Bambang Sudarmanta \\ Jurusan Teknik Mesin, Fakultas Teknologi Industri, Institut Teknologi Sepuluh Nopember (ITS) \\ Jl. Arief Rahman Hakim, Surabaya 60111 Indonesia \\ e-mail: pascawinanda@riseup.net
}

\begin{abstract}
Abstrak-Salah satu sumber energi terbarukan yang berpotensi dikembangkan di tanah air ialah etanol. Ethanol memiliki karakteristik yang mirip dengan Premium dengan nilai RON sebesar 108. Dalam penelitian ini, ingin diketahui karakteristik unjuk kerja serta emisi gas buang mesin bensin menggunakan bahan bakar campuran ethanol $99.5 \%$ dengan premium setelah uji durability selama 5000 KM. Dalam penelitian ini pula ingin diketahui pengaruh pemakaian campuran ethanol $99.5 \%$ dengan premium pada ruang bakar dan minyak pelumas setelah digunakan selama 5000 KM. Pengujian dilakukan dengan uji durability mobil sejauh $5000 \mathrm{~km}$ dengan bahan bakar campuran ethanol dan bensin dengan variasi campuran ethanol sebesar $5 \%, 10 \%$, dan $15 \%$, pengukuran meliputi kandungan minyak pelumas dan visualisasi ruang bakar. Selanjutnya dilakukan pengujian di Laboratorium Teknik Pembakaran dan Bahan Bakar Jurusan Teknik Mesin FTIITS dengan menggunakan mesin bensin empat langkah Toyota Vios dengan variasi campuran ethanol sebesar 5\%, $10 \%$, dan $15 \%$ dengan putaran mesin 3000 hingga 6000 rpm. Pengukuran meliputi torsi, daya, waktu konsumsi bahan bakar, $T$ oli, $T$ radiator, dan $T$ exhaust serta emisi gas $\mathrm{HC}$, CO dan CO2. Hasil uji eksperimental menunjukkan penambahan bioetanol pada bahan bakar bensin premium cenderung meningkatkan densitas dan viskositas tetapi menurunkan nilai kalor. Sedangkan unjuk kerja cenderung mengalami peningkatan performa dan terjadi penurunan emisi. Torsi, daya dan bmep tertinggi didapatkan oleh campuran E10 dengan kenaikan masingmasing sebesar $2,40 \%, 2,94 \%$ dan $2,72 \%$ dibandingkan dengan premium. Sedangkan konsumsi bahan bakar spesifik (sfc) terendah didapatkan oleh campuran E10 dengan penurunan sebesar $4,14 \%$ dibandingkan dengan premium. Karakteristik minyak pelumas untuk bahan bakar E5, E10 dan E15 relatif stabil seperti bahan bakar premium. Pencampuran bioetanol pada premium cenderung menurunkan suhu operasional mesin, yaitu mencapai 3,02\% pada campuaran $15 \%$. Untuk visualisasi ruang bakar pemakaian bahan bakar E5, E10 dan E15 menghasilkan pengotoran relatif lebih tipis dibandingkan bahan bakar premium. Secara akeseluruhan penambahan bioetanol sampai $15 \%$ tidak mengalami perubahan pada kondisi operasional mesin.
\end{abstract}

Kata Kunci-energi terbarukan, ethanol, premium, durability, unjuk kerja.

\section{Pendahuluan}

K etergantungan manusia terhadap energi tak terbarukan semakin lama semakin meningkat seiring dengan bertambahnya jumlah populasi manusia. Ditambah lagi belum optimalnya penggunaan energi terbarukan menyebabkan manusia sulit untuk lepas dari ketergantungan terhadap energi tak tebarukan.
Konsekuensinya adalah semakin menipisnya cadangan energi tak terbarukan tersebut. Bahkan diperkirakan dunia akan mengalami krisis besar energi pada tahun 2050 saat cadangan minyak bumi dan batu bara yang terkandung dalam perut bumi habis. Cadangan minyak bumi di Indonesia pun cenderung semakin turun sedangkan konsumsi semakin meningkat. Hal ini yang mengakibatkan Indonesia sudah menjadi negara net importer yang berarti bahwa konsumsi bahan bakar minyak Indonesia sebagian besarnya dipasok dari negara lain.

Berdasarkan keadaan tersebut, pemerintah telah membuat roadmap yang jelas terkait diversifikasi energi dengan mencanangkan BBN (Bahan Bakar Nabati) sebagai pengganti BBM, seperti yang tertera pada tabel. Guna menyikapi dan mendukung berjalannya roadmap yang telah dibuat, pemerintah mendirikan pabrik bioetanol, PT Energi Agro Nusantara (Enero) dengan kapasitas sebesar 100 ribu kiloliter per hari. Dengan berdirinya pabrik bioethanol yang berbahan dasar molases ini diharapkan dapat memenuhi kuota bioethanol dalam negeri yang nantinya dicampurkan dengan premium Pertamina, sesuai dengan yang tertuang dalam UU Energi No.30 2007. Namun dengan berbagai macam kendala, baik itu dari sisi teknis maupun dari segi kebijakan pemerintah, mengakibatkan pengembangan bioetanol ini masih jalan di tempat. Bahkan karena tidak terserapnya produksi bioetanol oleh Pertamina, PT Enero mengekspor bioetanol ke sejumlah Negara.

TABEL 1. ROADMAP ENERGI TERBARUKAN NASIONAL ${ }^{[1]}$

\begin{tabular}{|c|c|c|c|}
\hline & 2005-2010 & 2011-2015 & 2016-2025 \\
\hline Bioetanol & $\begin{array}{c}\text { 5\% dari konsumsi } \\
\text { 1,48 juta } \mathrm{KL}\end{array}$ & $\begin{array}{c}10 \% \text { dari konsumsi } \\
2,78 \text { juta KL. }\end{array}$ & $\begin{array}{c}\text { 15\% dari konsumsi 6,28 } \\
\text { juta KL. }\end{array}$ \\
\hline Biodiesel & $\begin{array}{c}10 \% \text { dari konsumsi } \\
\text { 2,41 juta KL }\end{array}$ & $\begin{array}{c}\text { 15\% dari konsumsi } \\
\text { 4,52 juta KL }\end{array}$ & $\begin{array}{l}\text { 20\% dari konsumsi 10,22 } \\
\text { juta KL }\end{array}$ \\
\hline BioKerosine & 1 juta KL. & 1,8 juta KL & 4,07 juta KL \\
\hline $\begin{array}{l}\text { Bio nabati murni } \\
\text { untuk } \\
\text { pembangkit } \\
\text { listrik }\end{array}$ & 0,4 juta KL & 0,74 juta KL & 1,69 juta KL \\
\hline Biofuel & $\begin{array}{c}\text { 2\% dari konsumsi } \\
\text { 5,29 juta KL }\end{array}$ & $\begin{array}{c}\text { 3\% dari konsumsi } \\
\text { 9,84 juta KL }\end{array}$ & $\begin{array}{c}\text { 5\% dari konsumsi 22,26 } \\
\text { juta KL }\end{array}$ \\
\hline
\end{tabular}

Untuk mendapatkan unjuk kerja mesin yang optimal, diperlukan persentase kadar etanol yang sesuai. Dengan persentase kadar etanol yang tepat dalam campuran dengan premium maka dapat diperoleh pembakaran yang lebih baik. Dalam penelitian ini akan dilakukan analisa pengaruh penambahan kadar etanol dengan persentase 5\%, 10\% dan 15\% terhadap unjuk kerja mobil uji 1497 cc setelah menempuh jarak sejauh $500 \mathrm{~km}$. Penelitian ini juga ingin mengetahui pengotoran yang terjadi pada ruang bakar setelah uji durability sejalama $5000 \mathrm{~km}$. 
Selain itu penelitian ini bertujuan untuk mengetahui properties minyak pelumas setelah uji durability 5000 $\mathrm{km}$.

\section{Metodologi Penelitian}

Penelitian dilakukan dengan menggunakan metode eksperimental untuk mengetahui pengaruh penambahan ethanol $99.5 \%$ pada bahan bakar premium terhadap unjuk kerja da nemisi gas buang motor bensin injeksi multi silinder. Penelitian ini menggunakan tiga mobil yang mana tiap mobilnya mendapat perlakuan campuran bahan bakar yang berbeda.Variasi yang digunakan adalah dengan menambahkan ethanol $99.5 \%$ pada bahan bakar premium dengan kadar 5\% (E5), 10\% (E10), dan 15\% (E15), pada motor bensin $1497 \mathrm{cc}$ putaran variabel (variable speed test) 3000 hingga $6000 \mathrm{rpm}$. Spesifikasi mesin tertera pada Tabel 2.

TABel 2. SPESIFIKASI MESIN UJI

\begin{tabular}{cc}
\hline \hline Tipe Mesin & 4 cylinders, in-line $; 16$ valve \\
Isi Silinder & $1497 \mathrm{cc}$ \\
Daya Maksimum & $109 \mathrm{~kW}$ pada $6000 \mathrm{rpm}$ \\
Torsi Maksimum : & $14.4 \mathrm{Nm}$. pada $4200 \mathrm{rpm}$ \\
\hline \hline
\end{tabular}

Untuk mendapatkan hasil pengujian yang tepat dan akurat, dengan kondisi mobil yang telah menempuh jarak tempuh yang berbeda, maka ketiga mobil di tune up dan dilakukan pembersihan pengotoran pada ruang bakar. Kemudian pengotoran yang terjadi divisualisasikan. Setelah itu ketiga mobil menggunakan pelumas baru. Hal ini dilakukan agar kondisi mesin mobil dalam keadaan yang relatif sama. Untuk pengujian performa mobil digunakan dynamometer. Waktu konsumsi bahan bakar dihitung dengan tabung ukur bahan bakar $25 \mathrm{cc}$. Sensor AFR digunakan untuk mengetahui kesetimbangan udara pada campuran bahan bakar. Emisi gas buang diukur menggunakan STARGAS Exhaust Gas Analyzer. Termocouple digital digunakan untuk mengukur temperature pendingin, pelumas dan gas buang. Skema alat percobaan ditampilkan pada Gambar 1.1.

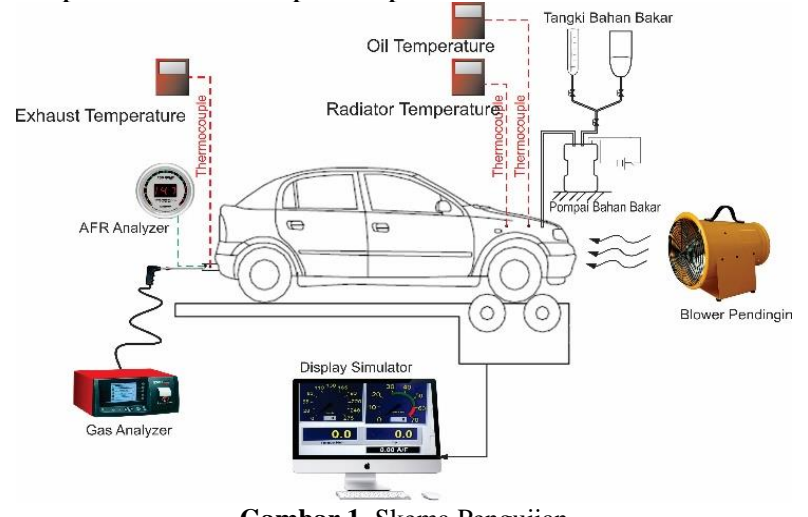

Gambar 1. Skema Pengujian

Campuran bahan bakar antara bensin dengan bioetanol disiapkan terlebih dahulu sesaat sebelum percobaan dimulai guna memperoleh campuran bahan bakar yang homogen dan mencegah bioetanol yang bereaksi terhadap air. Selain tiap mobil mendapat campuran bahan bakar bensin-bioetanol yang berbeda, ketiga mobil uji ini pun diuji dengan bahan bakar bensin murni (bioetanol $0 \%$ ). Rangkaian percobaan dimulai menggunakan mobil pertama dengan kadar campuran bioetanol 5\% (E5). Mobil ditempatkan sedemikian rupa pada alat dynamoneter. Kemudian mesin mobil dinyalakan pada putaran idle. Putaran mobil dinaikkan hingga 6000
rpm.Selama kenaikan putaran mesin, tabung ukur bahan bakar, sensor AFR, Exhaust Gas Analyzer dan Termocouple digital mengukur perubahan yang terjadi. Selain itu mencatat perubahan yang terjadi pada torsi dan daya mesin pada monitor digital dynamometer. Berikutnya percobaan dilanjutkan dengan dua mobil lainnya, campuran bioetanol $10 \%$ dan $15 \%$.

Percobaan dilanjutkan dengan uji pemakaian ketahanan mobil (durability test) dengan total jarak yang ditempuh sejauh $5000 \mathrm{~km}$ untuk mengetahui perubahan kondisi mobil yang terjadi. Pengemudi mencatat kondisi operasional per harinya, seperti jarak tempuh, konsumsi bahan bakar, suhu mesin, kemudahan starting awal, dan kondisi akselerasi. Setelah diuji durability, mobil diuji performa kembali seperti diawal. Selanjutnya mengambil sampel oli pada setiap mobil untuk dianalisis dan memvisualisasikan pengotoran yang terjadi pada komponen piston, injektor dan kepala silinder. Setelah rangkaian pengujian dengan ketiga mobil (E5, E10 dan E15) selesai, maka rangkaian pengujian dilakukan kembali dengan ketiga mobil dengan menggunakan bahan bakar bensin murni (bioetanol 0\%)

\section{URAIAN PENELITIAN}

Torsi merupakan ukuran kemampuan engine dalam menghasilkan kerja. Pada kehidupan sehari-hari torsi dari engine berguna untuk mengatasi hambatan di jalan atau untuk mempercepat laju kendaraan. Berdasarkan Gambar 2 s/d 4 menunjukkan bahwa adanya kecenderungan kenaikan torsi mulai dari putaran rendah hingga mencapai torsi maksimum pada putaran tertentu lalu torsi mengalami penurunan pada putaran yang lebih tinggi. Hal ini dikarenakan semakin tinggi putaran engine, massa campuran yang masuk ke ruang bakar semakin besar dan turbulensi aliran juga semakin tinggi sehingga menyebabkan pencampuran udara dengan bahan bakar semakin baik atau lebih homogen. Dengan campuran yang homogen, pembakaran akan berlangsung lebih baik sehingga menghasilkan torsi yang lebih tinggi. Sebaliknya, ketika putaran engine terus meningkat, kerugian gesek (friction losses) pada engine juga semakin tinggi sehingga sejumlah torsi digunakan untuk mengkompensasi kerugian tersebut. Disamping itu, semakin tinggi putaran engine waktu pembakaran (burning duration) akan berlangsung lebih cepat sehingga dimungkinkan terdapat bahan bakar yang tidak ikut terbakar. Hal tersebut dapat diindikasikan dari komposisi unsur yang tidak terbakar, yaitu $\mathrm{CO}$ dan $\mathrm{HC}$ pada gas buang yang relatif lebih tinggi. Hal tersebut mengakibatkan terjadinya penurunan nilai torsi sebagaimana ditunjukkan pada Gambar 2 s/d 4.

Nilai torsi tertinggi terjadi pada E10 sebesar $140 \mathrm{Nm}$ pada putaran $4400 \mathrm{rpm}$ Kenaikan nilai torsi rata-rata tertinggi terjadi pada E10 sebesar 4,20 \% dibanding bensin murni, sebagaimana komparasi secara keseluruhan ditunjukkan pada Gambar 3. Sedangkan setelah diuji durability sejauh $5000 \mathrm{~km}$ didapatkan nilai torsi tertinggi pada E10 sebesar $139 \mathrm{Nm}$ pada putaran 4400. Kenaikan torsi rata-rata tertinggi juga terjadi pada E10 dengan kenaikan sebesar 3,73\% dibanding bensin murni. Kenaikan nilai torsi ini dikarenakan kesesuaian komposisi antara bahan bakar dan udara pembakaran serta tahapan proses yang terjadi, mulai bahan bakar diinjeksikan kedalam saluran intake manifold, bercampur 
dengan udara pembakaran, dikompresi selama langkah kompresi, periode pengapian serta langkah buang gas hasil pembakaran. Dengan penambahan kadar bioetanol dalam campuran akan mengakibatkan campuran menjadi lebih miskin sehingga meningkatkan nilai air fue ratio. Dengan meningkatnya nilai air fuel ratio akan berpengaruh pada pembakaran yang lebih efisien. Angka oktan E5 yang lebih tinggi dari E0 meminimalisir terjadinya knocking pada ruang bakar sehingga didapatkan tekanan pembakaran yang lebih tinggi. Meningkatnya tekanan pembakaran secara otomatis akan meningkatkan nilai torsi ${ }^{[2]}$.

Daya yang dihasilkan oleh motor pembakaran dalam ada 3 jenis, yaitu indicative horse power (ihp), brake horse power (bhp), dan friction horse power (fhp). Pada putaran rendah, fhp relatif rendah dan akan semakin tinggi ketika putaran mesin semakin tinggi. Secara teoritis, ketika putaran mesin meningkat, maka daya motor juga akan meningkat karena daya merupakan perkalian antara torsi dengan putaran mesin. Akan tetapi, pada kenyataannya pada putaran engine yang tinggi tidak selalu menghasilkan daya yang tinggi. Hal ini dikarenakan pada putaran mesin yang tinggi berbagai kerugian dapat terjadi, seperti, friction losses, kenaikan temperatur overall engine, dan peristiwa overlapping.

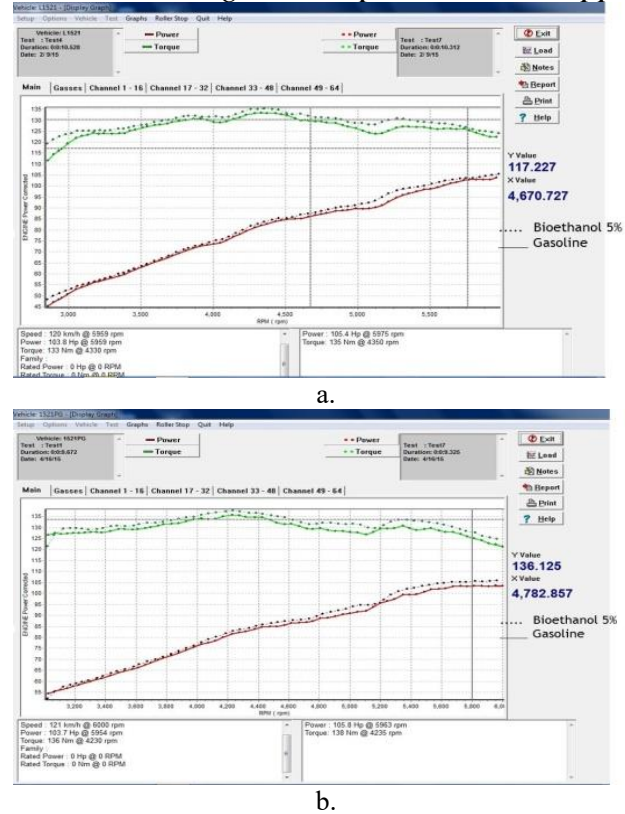

Gambar 2. Komparasi unjuk kerja daya dan torsi mobil 1 berbahan bakar bensin dan E5 pada, a. kondisi awal, b. setelah $5000 \mathrm{~km}$

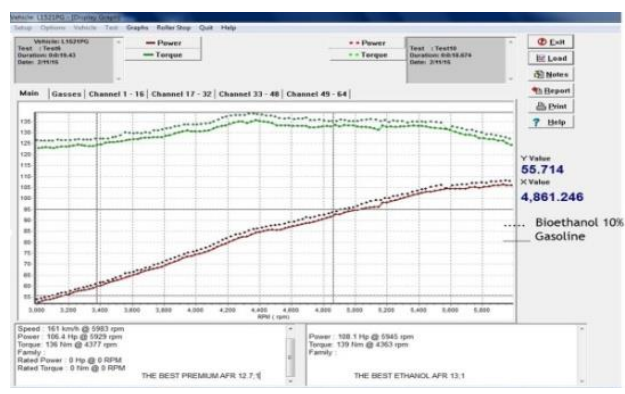

a.

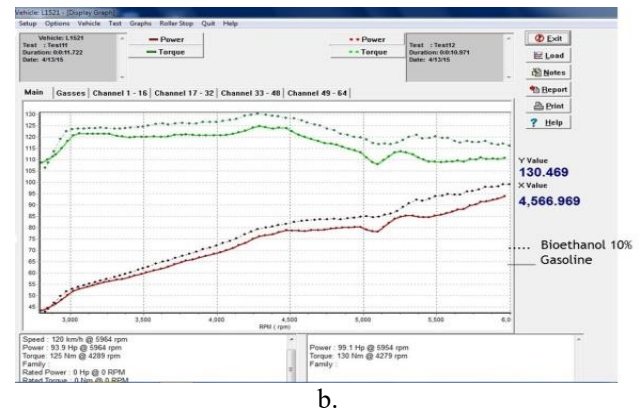

Gambar 3. Komparasi unjuk kerja daya dan torsi mobil 1 berbahan bakar bensin dan E10 pada, a. kondisi awal, b. setelah $5000 \mathrm{~km}$

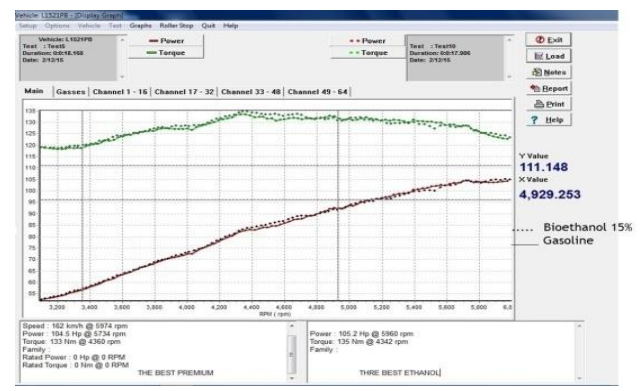

a.

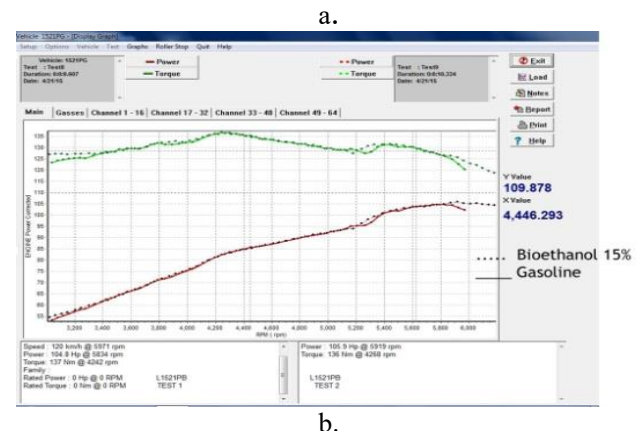

Gambar 4. Komparasi unjuk kerja daya dan torsi mobil 1 berbahan bakar bensin dan E15 pada, a. kondisi awal, b. setelah $5000 \mathrm{~km}$

Kenaikan daya secara rata-rata terjadi pada E10 sebesar 2,96\% dibanding bensin murni. Sedangkan setelah diuji durability sejauh $5000 \mathrm{~km}$ kenaikan kenaikan daya rata-rata juga terjadi pada E10 dengan kenaikan sebesar $3,12 \%$. Meningkatnya nilai daya dengan penambahan bioetanol dalam campuran seperti ditunjukkan pada Gambar 3 disebabkan bioetanol memiliki nilai latent heat of evaporation yang jauh lebih tinggi dibanding bensin. Dengan nilai latent heat of evaporation yang tinggi mengakibatkan bahan bakar cenderung mengambil kalor dalam udara untuk menguap sehingga menurunkan temperatur udara pada engine. Turunnya temperatur udara (cooling effect) berpengaruh pada meningkatnya densitas campuran bahan bakar sehingga meningkatkan efisiensi volumeris. Meningkatnya efisiensi volumetris inilah yang menyebabkan daya menjadi lebih tinggi. Berdasarkan Gambar 3 dapat dilihat bahwa tren grafik pada penggunaan bahan bakar bensin dan campuran E10 memiliki kecenderungan pada 3000 rpm hingga 5000 rpm memiliki kecenderungan naik. Hal ini dikarenakan besarnya nilai sfc sangat ditentukan oleh besarnya flowrate bahan bakar dan daya dihasilkan oleh engine. Hal ini dikarenakan semakin besar putaran engine maka terjadinya friction loss juga semakin besar sehingga menyebabkan sfc juga meningkat. Secara umum dengan penambahan kadar bioetanol dalam campuran menyebabkan kenaikan konsumsi bahan bakar, karena untuk menghasilkan keluaran daya yang sama, dengan nilai low heating value bioetanol yang kecil 
menyebabkan konsumsi bahan bakar cenderung meningkat. Adapun kecenderungan tren grafik E10 yang nilainya lebih rendah dibanding tren grafik sfc bensin bisa disebabkan efisiensi volumetris pada E10 yang lebih baik sehingga efisiensi pembakaran juga akan ikut naik. Efisiensi pembakaran yang naik ini dapat diakibatkan oleh kadar oksigen dalam bioetanol yang cukup tinggi menyebabkan konsumsi bahan bakar turun. Disini bisa disimpulkan bahwa selama kadar bioetanol tidak melebihi $10 \%$, maka naiknya konsumsi bahan bakar tidak bergantung pada kenaikan kadar bioetanol dalam campuran. Sebaliknya bila diatas $10 \%$, maka sfc akan semakin meningkat seiring bertambahnya kadar bioetanol dalam campuran ${ }^{[3]}$. Besarnya specific fuel consumption minimum engine sebesar 0,32 kg/hp.jam pada 3000 rpm. Dibandingkan dengan bahan bakar bensin, penurunan maksimum dengan memakai bahan bakar E10 sebesar 7,92\%, sedangkan penurunan rataratanya sepanjang putaran engine mencapai $5,79 \%$.

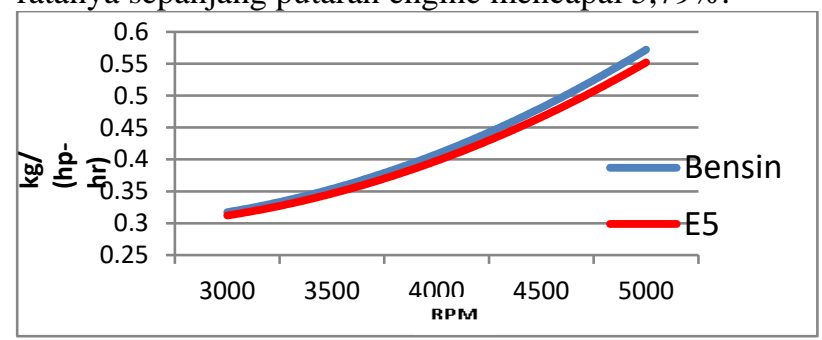

Gambar 5. Besarnya sfc mobil 1

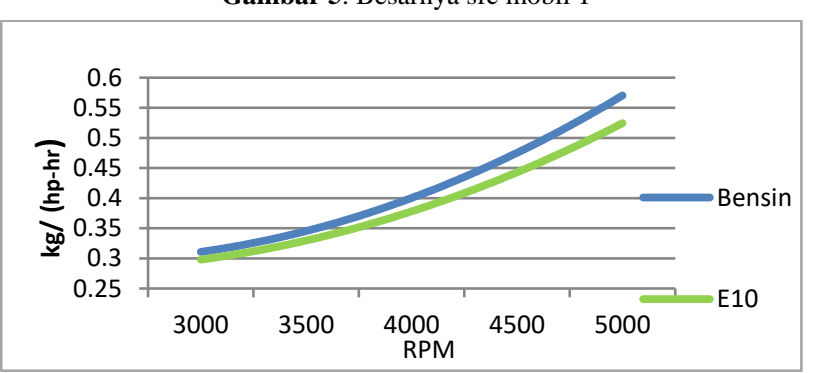

Gambar 6. Besarnya sfc mobil 2

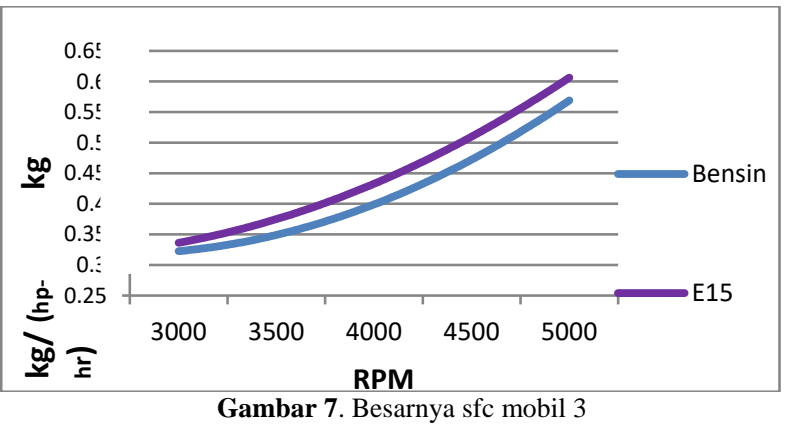

Efisiensi thermal adalah ukuran besarnya pemanfaatan energi panas yang tersimpan dalam bahan bakar untuk diubah menjadi daya efektif oleh motor pembakaran dalam. Pada gambar 7 menunjukkan bahwa efisiensi optimum tertinggi didapat ketika engine menggunakan bahan bakar bensin dengan penambahan $10 \%$ sebesar $13,63 \%$ dibanding bensin pada putaran engine $3000 \mathrm{rpm}$, sedangkan efisiensi optimum terendah dihasilkan ketika engine menggunakan bahan bakar bensin dengan penambahan 5\% ethanol sebesar 1,58\% dibanding bensin pada putaran engine $5000 \mathrm{rpm}$. Secara rata-rata, apabila dibandingkan menggunakan engine berbahan bakar Premium murni besarnya peningkatan efisiensi thermal apabila ditambahkan $10 \%$ ethanol $99.5 \%$ adalah 14,7 $\%$.Secara umum, dengan penambahan $5 \%, 10 \%$ dan $15 \%$ ethanol efisiensi thermal cenderung meningkat. Hal ini diakibatkan karena pada penambahan ethanol dengan konsentrasi tersebut akan menghasilkan campuran kimia yang tepat. Selain itu bisa juga diakibatkan oleh pengkabutan bahan bakar yang lebih baik, sehingga atomisasi bahan bakar menjadi lebih baik dan menghasilkan pembakaran yang lebih baik pula. Hal ini dapat dibuktikan dengan emisi gas buang HC E5, E10 dan E15 yang lebih rendah dibanding bensin (Gambar 12).

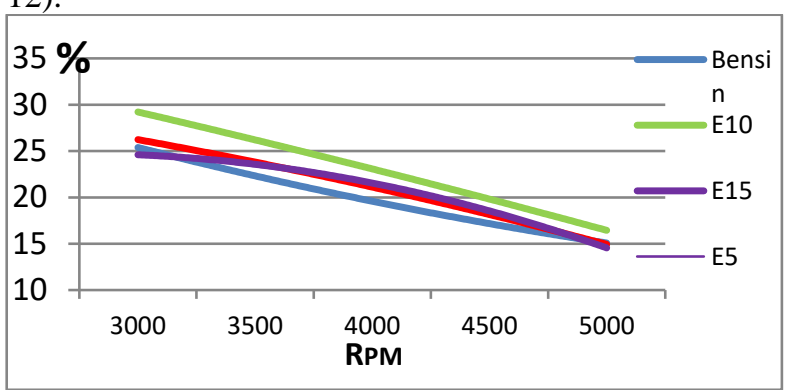

Gambar 8 Perbandingan efisiensi thermal

Dari grafik bmep fungsi putaran engine, terlihat adanya tren kenaikan tekanan efektif rata-rata mulai dari putaran rendah hingga mencapai tekanan efektif rata-rata maksimum pada putaran tertentu lalu bmep mengalami penurunan pada putaran engine yang lebih tinggi. Pada gambar 4.20 diatas menunjukkan bahwa tekanan effektif rata-rata maksimum yang tertinggi dihasilkan pada engine yang menggunakan bahan bakar E10 dengan tekanan efektif rata-rata maksimum sebesar $1159,92 \mathrm{kPa}$ pada putaran engine $5000 \mathrm{rpm}$. Pada pengujian unjuk kerja setelah uji durability $5000 \mathrm{~km}$ pada Gambar 8 tampak Bmep tertinggi terjadi pada persentase bioetanol $10 \%$ dengan nilai tertinggi pada putaran $4500 \mathrm{rpm}$ dengan nilai bmep sebesar 1169,22 kPa. Pada grafik itu pula diperlihatkan nilai bmep terendah terjadi pada E0 dengan nilai bmep sebesar 1046,32 $\mathrm{kPa}$ pada putaran $4000 \mathrm{rpm}$.
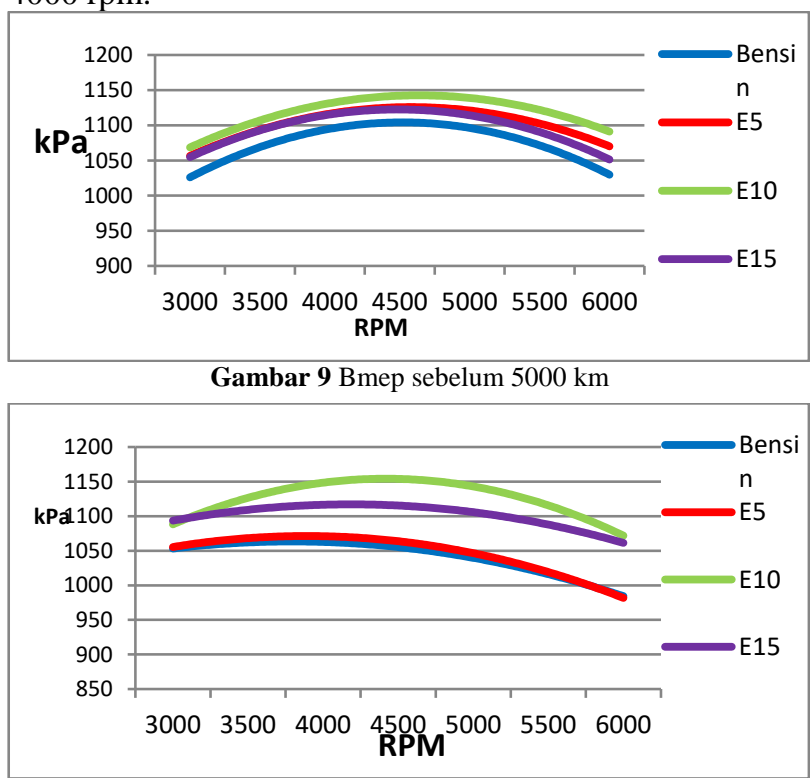

Gambar 10. Bmep setelah $5000 \mathrm{~km}$

Nilai minimum emisi $\mathrm{CO}$ adalah pada bahan bakar campuran E10 dan E 15, yaitu sebesar 0,5\% pada putaran mesin 3000 rpm. Secara keseluruhan rata-rata emisi CO terendah terjadi pada E15 dengan penurunan mencapai $15,30 \%$, sedangkan untuk E10 penurunannya $13,57 \%$. Nilai minimum emisi HC ketika engine menggunakan bahan bakar E10 dengan emisi HC sebesar 65 ppm. 
Secara rata-rata emisi HC E10 mengalami penurunan sebesar $11,79 \%$ dibandingan bahan bakar bensin.

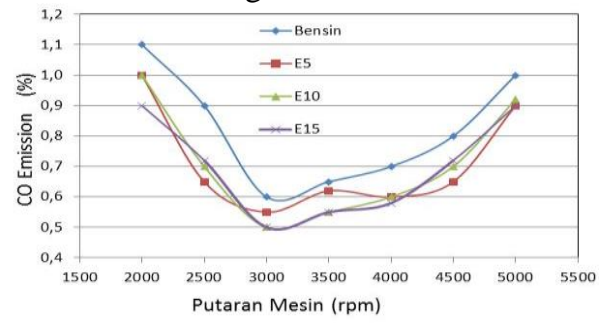

Gambar 11. Emisi CO Mobil uji setelah uji durability

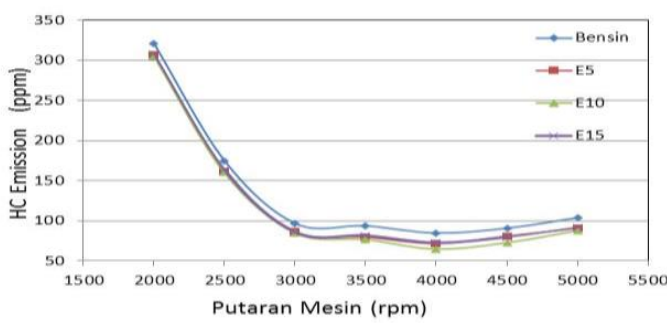

Gambar 12. Emisi HC Mobil uji setelah uji durability

Pada Gambar 13 di atas menunjukkan besarnya oli pelumas terhadap putaran mesin. Dari pengujian bahan bakar premium murni dan campuran premium dengan bioetanol E5, E10 dan E15 menunjukkan bahwa pemakaian campuran E5, E10 dan E15 dapat menurunkan besarnya suhu oli pelumas ${ }^{[4]}$. Dibandingkan dengan rata-rata suhu oli pelumas menggunakan premium murni, campuran E5 mengalamai penurunan sebesar 6,55 \%, campuran E10 mengalamai penurunan 2, 98\% dan campuran E15 mengalami penurunan $8,33 \%$. Penurunan suhu oli pelumas terjadi karena campuran bioetanol memiliki nilai kalor yang lebih rendah dibandingkan premium, sehingga pelepasan kalor selama proses pembakaran lebih rendah.

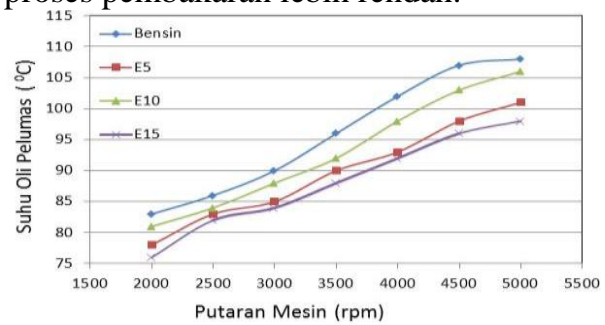

Gambar 13. Suhu oli pelumas setelah uji durability

Pada Gambar 14 dapat dilihat bahwa secara umum terjadi penurunan temperatur exhaust ketika menggunakan bahan bakar campuran dengan bioetanol, baik E5, E10 maupun E15. Nilai temperatur maksimum exhaust ketika menggunakan bahan bakar premium mencapai $500^{\circ} \mathrm{C}$ pada putaran $5000 \mathrm{rpm}$ dan pada saat menggunakan bahan bakar campuran dengan bioetanol suhu exhaust dibawah $470^{\circ} \mathrm{C}$. Penurunan suhu exhaust gas terjadi karena campuran bioetanol memiliki nilai kalor yang lebih rendah dibandingkan premium, sehingga pelepasan kalor selama proses pembakaran lebih rendah [5].

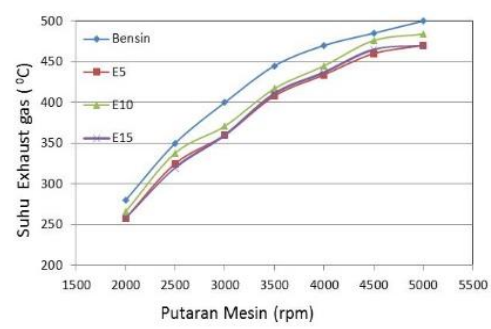

Gambar 14 Suhu exhaust gas setelah uji durability
Berdasarkan properties minyak pelumas untuk mobil uji setelah dioperasikan sejauh $5000 \mathrm{~km}$ menunjukkan bahwa pencampuran premium dengan bioetanol menyebabkan hal-hal sebagai berikut:

TABEL 3. PROPERTIES MINYAK PELUMAS MOBIL BENSIN MURNI

\begin{tabular}{|c|c|c|c|c|}
\hline \multicolumn{5}{|c|}{ SETELAH $5000 \mathrm{KM}$} \\
\hline \multirow{2}{*}{ PARAMETER } & \multicolumn{3}{|c|}{ HASIL uji } & \multirow{2}{*}{ UNIT } \\
\hline & Mobil 1 (bensin) & Mobil 2 (bensin) & Mobil 3(bensin) & \\
\hline Kinematic Viscosity at $40^{\circ}$ & 76,6 & 70 & 74,46 & CST \\
\hline Kinematic Viscosity at $100^{\circ}$ & 11,1 & 11,02 & 11,75 & CST \\
\hline Densitas $15^{\circ}$ & 0,87 & 0,86 & 0,87 & $\mathrm{~g} / \mathrm{ml}$ \\
\hline Flash Point & 198 & 206 & 198 & c \\
\hline Water Content & 0,22 & 0,32 & 0,12 & $\%$ \\
\hline $\mathrm{Fe}$ & 14,86 & 18,68 & 16,42 & PPM \\
\hline Al & 3,82 & 3,22 & 2,44 & PPM \\
\hline $\mathrm{Cu}$ & 0,36 & 0,24 & 0,3 & PPM \\
\hline $\mathrm{Ni}$ & 1,62 & 1,24 & 2,1 & PPM \\
\hline $\mathrm{Pb}$ & tidak teridentifikasi & tidak teridentifikasi & tidak teridentifikasi & PPM \\
\hline $\mathrm{Cr}$ & tidak teridentifikasi & tidak teridentifikasi & tidak teridentifikasi & PPM \\
\hline TAN/TBN & 24,2 & 14,8 & 18,24 & $\mathrm{mg} \mathrm{KOH} / \mathrm{g}$ \\
\hline
\end{tabular}

TABEL 4. PROPERTIES MINYAK PELUMAS MOBIL BENSIN-BIOETANOL

\begin{tabular}{|c|c|c|c|c|}
\hline \multicolumn{5}{|c|}{ SETELAH $5000 \mathrm{KM}$} \\
\hline \multirow{2}{*}{ PARAMETER } & \multicolumn{3}{|c|}{ HASIL uji } & \multirow{2}{*}{ UNIT } \\
\hline & Mobil 1(E5) & Mobil 2 (E10) & Mobil 3(E15) & \\
\hline Kinematic Viscosity at $40^{\circ}$ & 76,91 & 70,08 & 74,83 & CST \\
\hline Kinematic Viscosity at $100^{\circ}$ & 12,27 & 11,87 & 12,86 & CST \\
\hline Densitas $15^{\circ}$ & 0,87 & 0,87 & 0,87 & $\mathrm{~g} / \mathrm{ml}$ \\
\hline Flash Point & 188 & 192 & 196 & c \\
\hline Water Content & 0,1 & 0,11 & 0,08 & $\%$ \\
\hline $\mathrm{Fe}$ & 15,05 & 17,96 & 15,41 & PPM \\
\hline $\mathrm{Al}$ & 4 & 2,66 & 2,03 & PPM \\
\hline $\mathrm{Cu}$ & 0,38 & 1,83 & 0,35 & PPM \\
\hline $\mathrm{Ni}$ & 1,32 & 1,43 & 1,29 & PPM \\
\hline $\mathrm{Pb}$ & tidak teridentifikasi & tidak teridentifikasi & tidak teridentifikasi & PPM \\
\hline $\mathrm{Cr}$ & tidak teridentifikasi & tidak teridentifikasi & tidak teridentifikasi & PPM \\
\hline TAN/TBN & 25,89 & 14,9 & 20,89 & $\mathrm{mg} \mathrm{KOH} / \mathrm{g}$ \\
\hline
\end{tabular}

Viskositas kinematis relatif lebih tahan dibandingkan dengan bahan bakar premium

[1] Densitas dan flash point relatif stabil

[2] Water content mengalami penurunan tipis

[3] Kandungan unsur-unsur relatif tidak ada perubahan

[4] TAN mengalami sedikit kenaikan

Visualisasi pengotoran ruang bakar dimaksudakan untuk mengetahui pengaruh pemakaian bahan bakar campuran premium dan bioetanol dan bahan bakar murni setelah pemakaian $5.000 \mathrm{~km}$. Hal ini sangat penting mengingat faktor pengotoran dapat mempengaruhi unjuk kerja dan umur mesin. Visualisasi pengotoran yang dilakukan meliputi visualisasi pada casing samping, visualisasi pada piston dan combustion chamber, visualisasi pada cylinder head pandangan atas maupun pandangan bawah serta visualisasi pada busi. Mobil 1, 2 dan 3 secara berturut-turut adalah mobil yang pada saat uji durability bioetanol menggunakan kadar 5, 10 dan $15 \%$. Sedangkan saat uji durability bensin, semua mobil menggunakan $100 \%$ bensin. Pada pemakaian $5.000 \mathrm{~km}$ dengan memakai bahan bakar E5, E10, E15 dan premium murni relatif tidak menunjukkan perbedaan yang berarti, hanya pengotoran oli pada bahan bakar premium murni lebih banyak. Sedangkan pengotoran yang menempel permanen relatif tidak ada.

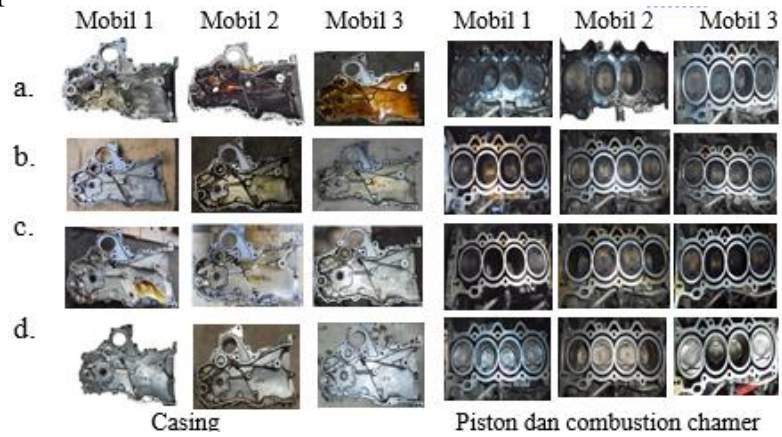


a.

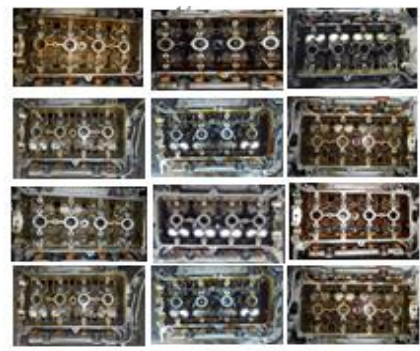

Cylinder Head Atas

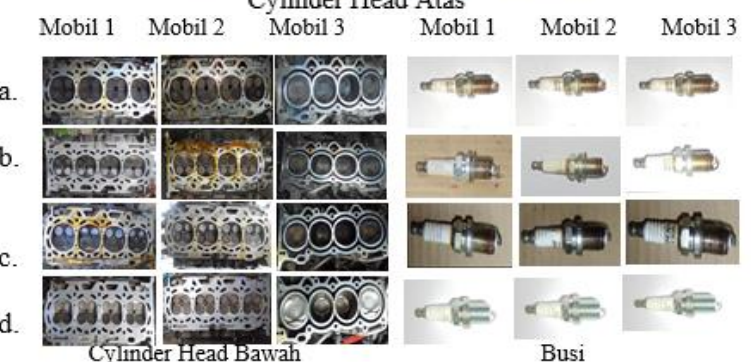

Gambar 15. Visualisasi ruang bakar a).sebelum pengujian, b).setelah pengujian $5000 \mathrm{~km}$ bioetanol, c). setelah pengujian $5000 \mathrm{~km}$ bensin, d).setelah dibersihkan

\section{KESIMPULAN/RINGKASAN}

Dari penelitian ini dapat disimpulkan kenaikan tetinggi torsi rata-rata sebesar $4,2 \%$ pada $\mathrm{E} 10$, daya rata-rata tertinggi pada E10 dengan kenaikan 2,96\% dibanding bensin murni. Penurunan SFC tertinggi terjadi pada E10 sebesar 7,92\%. Bmep tertinggi pada E10 sebesar 2,72\%. Emisi gas CO terendah didapatkan oleh campuran E10 dan E15 dengan penurunan sebesar 15,30\%. Emisi gas HC terendah didapatkan oleh campuran E10 dengan penurunan sebesar $11,79 \%$. Karakteristik minyak pelumas untuk bahan bakar E5, E10 dan E15 relatif stabil seperti bahan bakar premium, tidak terjadi keausan dan korosi pada mesin maupun kerusakan pada karet seal.
Pemakaian bahan bakar E5, E10 dan E15 menghasilkan pengotoran relatif lebih tipis dibandingkan bahan bakar premium. Secara keseluruhan penambahan bioetanol sampai $15 \%$ tidak mengalami perubahan pada kondisi operasional mesin, baik itu tempertur mesin, tarikan maupun penyalaan mesin saat kondisi dingin sehingga secara teknis dapat dikatakan operasionalnya lancar dan tidak terkendala.

\section{UCAPAN TERIMA KASIH}

Penulis mengucapkan terima kasih pada PT PTPN X, PT Enero, Laboratorium Teknik Pembakaran dan Bahan Bakar setelah seluruh teman-teman lab yang telah membantu terwujudnya penelitian ini.

\section{DAFTAR PUSTAKA}

[1] Kementerian Energi dan Sumber Daya Mineral ,"Kebijakan Energi Nasional", Rakornas Tentang Revitalisasi Pendidikan, Bio Energi dan Penanganan Bencana Alam, Agustus: Jakarta,2006.

[2] G. Najafi, B. Ghobadian, T. Tavakoli, D.R. Buttsworth "Performance and exhaust emissions of a gasoline engine with ethanol blended gasoline fuels using artificial neural network": Elsevier, 2009.

[3] Elfasakhany: Investigations on the effects of ethanolemethanolegasoline blends in a spark-ignition engine: Performance and emissions analysis: Elsevier, A. Elfasakhany: 2015.

[4] Setiyawan, Atok, Kajian Eksperimental Pengaruh Etanol Pada Premium terhadap Karakteristik Pembakaran Kondisi Atmosferik Dan Bertekanan Di Motor Otto Silinder Tunggal Sistem Injeksi, Jakarta: Universitas Indonesia,2012.

[5] Da Silva R., Renanto Cataluna, E.W. de Menezes ,"Effect additives on the antiknock properties and Reid vapour pressure og gasoline", Fuel Vol 84., pp. 951-9, Elsevier,2005. 